\title{
ANALYSIS AND CORRELATIONS OF DIMENSIONLESS NUMBERS RELEVANT TO ORIFICES' CAVITATING FLOW
}

\author{
Abdul-Fattah Mohammed Ali ${ }^{1,2}$ \\ AND MOHANAD JASIM MOHAMMED-RIDHA ${ }^{1 *}$ \\ ${ }^{1}$ Department of Environmental Engineering, University of Baghdad, Baghdad, Iraq \\ ${ }^{2}$ Department of Oil and Gas Refining Engineering, \\ Al-Farabi University College, Baghdad, Iraq \\ *Corresponding author: muhannadenviro@coeng.uobaghdad.edu.iq
}

(Received: $5^{\text {th }}$ December 2019; Accepted: $13^{\text {th }}$ May 2020; Published on-line: $4^{\text {th }}$ July 2020)

\begin{abstract}
The aim of this work was to establish a general design basis for pilot-scale units to treat textile dyeing wastewater containing recalcitrant organic chemicals by hydrodynamic cavitation (HC) using orifices of various geometries. Relevant tabulated data available in the literature were analyzed and correlated to obtain universal relationships to this end. In spite of extensive effort, most of the obtained correlations were system-specific, which still can be used for design using their respective orifice geometries as demonstrated. However, one salient general relationship links the pipe's dimensionless loss coefficient $\left(K_{L P}\right)$ to the pipe's Reynolds number $\left(\operatorname{Re}_{P}\right)$, encompassing all data under consideration, which may serve as an additional design option to optimize such units. The implication of this relationship is a lower upstream pressure $\left(\mathrm{P}_{1}\right)$ value with an increase in pipe diameter while using the same specified orifice and achieving the same desired cavitation number $\left(\mathrm{C}_{\mathrm{v}}\right)$. The ratio of $\mathrm{P}_{1}$ value in the larger pipe to its value in the smaller pipe is a function of the smaller pipe diameter $\left(D_{S}\right)$ to the larger pipe diameter $\left(D_{L}\right)$ ratio: $\left(P_{1}\right.$ in $\left.D_{L}\right) /\left(P_{1}\right.$ in $\left.D_{S}\right)=\left(D_{S} / D_{L}\right)^{2.33}$. A lower $P_{1}$ value will increase the cavitation yield by decreasing the expended energy, especially if the required number of passes is large. Additionally, the variation of the orifices' hole loss coefficient $\left(\mathrm{K}_{\mathrm{Lh}}\right)$ with the ratio of the holes area to the pipe cross-sectional area $\left(A_{h} / A_{p}\right)$ for cavitating flow is compared with that for non-cavitating/incipient cavitation flow reported in the literature.
\end{abstract}

ABSTRAK: Tujuan kajian ini diadakan bagi mereka bentuk dasar umum unit skalapandu bagi merawat pewarnaan air buangan tekstil yang mengandungi kimia organik rekalsitran daripada peronggaan hidrodinamik (HC) menggunakan orifis pelbagai geometri. Data berjadual berkaitan yang ada dalam kajian lepas dianalisa dan dikaitkan bagi mendapatkan kaitan universal hingga akhir. Walaupun pelbagai usaha telah dijalankan, banyak kaitan didapati mengguna pakai sistem-tertentu, di mana boleh digunakan bagi mereka cipta menggunakan geometri orifis yang ditunjukkan. Walau bagaimanapun, bagi menghubung kait pekali langsung tanpa dimensi $\left(\mathrm{K}_{\mathrm{LP}}\right)$ kepada paip nombor Reynolds $\left(\operatorname{Re}_{\mathrm{P}}\right)$, meliputi semua data di bawah pertimbangan, di mana membantu pilihan rekaan tambahan bagi mengoptimum unit tersebut. Implikasi hubungan ini adalah nilai tekanan hulu sungai bawah $\left(\mathrm{P}_{1}\right)$ dengan penambahan diameter paip dengan menggunakan orifis sama yang sebenar dan mendapati nombor peronggaan yang sama diingini $\left(\mathrm{C}_{\mathrm{v}}\right)$. Nisbah nilai $\mathrm{P}_{1}$ dalam paip besar kepada nilai paip kecil adalah berkadaran pada nisbah diameter paip kecil $\left(D_{S}\right)$ kepada diameter paip besar $\left(D_{L}\right)$ :

$\left(\mathrm{P}_{1}\right.$ dalam $\left.\mathrm{D}_{\mathrm{L}}\right) /\left(\mathrm{P}_{1}\right.$ in $\left.\mathrm{D}_{\mathrm{S}}\right)=\left(\mathrm{D}_{\mathrm{S}} / \mathrm{D}_{\mathrm{L}}\right)^{2.33}$. 
Nilai $\mathrm{P}_{1}$ yang lebih kecil akan menambah jumlah peronggaan dengan pengurangan tenaga pengembangan, terutama jika nombor laluan yang diperlukan adalah besar. Tambahan, variasi orifis pekali langsung lubang $\left(\mathrm{K}_{\mathrm{Lh}}\right)$ dengan nisbah keluasan lubang kepada ruang keratan-rentas paip $\left(\mathrm{A}_{h} / \mathrm{A}_{\mathrm{p}}\right)$ bagi alur rongga dibandingkan dengan bukan rongga / permulaan rongga alur telah dilapor dalam kajian

KEYWORDS: hydrodynamic cavitation; orifice geometry; cavitation numbers; upstream pressure; loss coefficients

\section{INTRODUCTION}

Hydrodynamic cavitation (HC) is a well-established technique for a variety of applications including the treatment of wastewater containing pharmaceuticals [1], insecticides [2], phenolic compounds [3], and textile dyes [4-8]. HC is usually combined with the addition of an oxidizing agent $\left(\mathrm{H}_{2} \mathrm{O}_{2}, \mathrm{NaOCl}\right.$, etc.) or with acoustic cavitation to achieve an acceptable cavitation yield (CY) which is defined as the cavitation effect per unit energy supplied to the system.

Over the last two decades, many HC research studies have been published, some with detailed tabulated data. Their size-scale ranged from $1 \mathrm{~L}$ lab units to $50 \mathrm{~L}$ pilot ones. Various devices were used to induce HC in these units such as single-/multi-hole orifices, venturis, stator-rotor equipment, etc. The operational mode was batch-wise based either on fixed time or on a specified number of passes (turnovers) where the wastewater volume was recirculated many times through the $\mathrm{HC}$ device to achieve an acceptable CY. This could be hundreds of times, lasting over two hours depending on the system's flow rate (e.g. 260 passes lasting $130 \mathrm{~min}$ [7]).

Single-/multi-hole orifices as $\mathrm{HC}$ inducing devices are simpler to manufacture and install than other alternatives which explain their wide use in $\mathrm{HC}$ studies. Their hole size generally ranges from 1 to $5 \mathrm{~mm}$ with multi-hole counts of $8,16,20,25$, or 33 , although some studies used sizes and counts outside these values. The pipes in which the aforementioned orifices were placed had inside diameters ranging from 4 to $53 \mathrm{~mm}$.

The results obtained in all previously published HC studies were system-specific; a generalized or unifying approach were markedly lacking. Reviews stated only general trends based on the published works. Consequently, it is difficult to make practical use of available information, specifically a priori design of a functional wastewater-treating HC unit, save adopting a given system with all its particulars. The present work is an attempt at a unifying approach, relying entirely on tabulated data from a number of published research studies. The outcome of this endeavor was only partially productive as will be illustrated later by the obtained results. This research did not receive any specific grant from funding agencies in the public, commercial, or not-for-profit sectors.

\section{GEOMETRICAL DETAILS AND REFERENCES OF ORIFICES WHOSE HC PUBLISHED DATA WERE USED IN THIS WORK}

Two categories of published data were excluded from the analysis and correlations performed in this study. The first concerned orifices with a hole size of one mm or less, whether single- or multi-hole ones. One $\mathrm{mm}$ holes or smaller are difficult/expensive to produce locally while ensuring their integrity (sharp edge, lack of burrs, etc.). The second category concerned a $\mathrm{HC}$ system in which the fully-recovered orifice's downstream pressure $\left(\mathrm{P}_{2}\right)$ was higher than atmospheric pressure (i.e. $\mathrm{P}_{2}>$ one atm. abs. or zero gage). 
Data with $\mathrm{P}_{2}>0$ gage did not match those with $\mathrm{P}_{2} \approx 0$ gage. Table 1 gives the details of the orifices whose $\mathrm{HC}$ data were used in this work along with their references.

The data of Testud et al. [10] and that of Mancuso et al. [7] were excluded due to $\mathrm{P}_{2}$ values being greater than one atm. abs. as pointed out earlier. It should be stressed that all the $\mathrm{HC}$ data of the references cited in Table 1 are relevant to pilot-scale units with $\mathrm{P}_{2} \approx$ one atm. abs. Hence, all the obtained correlations of this work are only relevant to such systems.

Table 1: Geometrical details and references of orifices whose HC data were employed in the analysis and correlations of this work.

\begin{tabular}{ccccc}
\hline $\begin{array}{c}\text { Hole dia. } \\
{[\mathbf{m m}]}\end{array}$ & $\begin{array}{c}\text { No. of } \\
\text { holes }\end{array}$ & $\begin{array}{c}\text { Pipe } \mathbf{I . D} \\
{[\mathbf{m m}]}\end{array}$ & $\mathbf{A}_{\mathbf{h}} / \mathbf{A}_{\mathbf{p}}$ & Reference \\
\hline 2 & 1 & 25.4 & $6.2 \times 10^{-3}$ & {$[6]$} \\
2 & 1 & 25 & $6.4 \times 10^{-3}$ & {$[9]$} \\
2 & 1 & 19 & 0.011 & {$[8]$} \\
2 & 1 & 19 & 0.011 & {$[17]$} \\
2 & 8 & 38 & 0.02216 & {$[11]$} \\
2 & 8 & 38 & 0.02216 & {$[4]$} \\
2 & 33 & 38 & 0.0914 & {$[11]$} \\
2 & 33 & 38 & 0.0914 & {$[4]$} \\
3 & 1 & 25.4 & 0.01395 & {$[6]$} \\
3 & 1 & 19 & 0.02493 & {$[17]$} \\
3 & 16 & 38 & 0.099723 & {$[11]$} \\
3 & 16 & 38 & 0.099723 & {$[4]$} \\
3 & 20 & 38 & 0.12465 & {$[11]$} \\
3 & 20 & 38 & 0.12465 & {$[4]$} \\
5 & 8 & 38 & 0.1385 & {$[11]$} \\
5 & 8 & 38 & 0.1385 & {$[4]$} \\
\hline
\end{tabular}

Notes: (i) $A_{h} / A_{p}$ is the ratio of the total area of holes to the cross-sectional area of the pipe. (ii) Thicknesses of orifices in Table 1 references were not mentioned, apart from Pawar et al. [9] which was $4 \mathrm{~mm}$ leading to an aspect ratio of 2 (aspect ratio = orifice thickness/hole dia.). (iii) $\mathrm{HC}$ data listed in Table 1 references are extensive and can be referred to; they shall not be repeated in this article. (iv) A 4-mm single hole orifice datum from Madhu et al. [6] was excluded due to lack of 4-mm multi-hole data.

\section{DIMENSIONLESS NUMBERS RELEVANT TO ORIFICE'S CAVITATING FLOW AND THEIR INTER-RELATIONSHIPS}

\subsection{Cavitation Number or Index}

There are several definitions for this parameter, the two most widely used ones are $\mathrm{C}_{\mathrm{V}}$ and $\sigma$ (notations used are similar to those in the cited references) defined as follows:

$$
\mathrm{C}_{\mathrm{v}}=\left(\mathrm{P}_{2}-\mathrm{P}_{\mathrm{v}}\right) /\left(0.5 \rho_{\mathrm{L}} \mathrm{u}_{\mathrm{o}}^{2}\right) \quad \text { and } \quad \sigma=\left(\mathrm{P}_{2}-\mathrm{P}_{\mathrm{v}}\right) /\left(\mathrm{P}_{1}-\mathrm{P}_{2}\right)
$$

where $\mathrm{P}_{1}, \mathrm{P}_{2}$ are the orifice's upstream and fully-recovered downstream pressures, respectively. $\mathrm{P}_{\mathrm{v}}$ is the liquid-vapor pressure and $\rho_{\mathrm{L}}$ is its density, both at the operating temperature. $u_{0}$ is the average liquid velocity at the orifice's hole (single hole or one hole in a multi-hole geometry).

Cavitating flow occurs when the value of $\mathrm{C}_{\mathrm{v}}($ or $\sigma)$ is usually $<1$, with an increase in cavitation intensity as the value of the index is lowered. Very low values of the index $(<$ 
0.1) may induce a regime called supercavitation which is counterproductive and should be avoided.

A modification of $\mathrm{C}_{\mathrm{v}}$ (called $\mathrm{C}_{\mathrm{v}}{ }^{\text {prime }}$ ) was introduced and used by Vichare et al. [11] and Sivakumar and Pandit [4] as a unifying approach for comparison of $\mathrm{HC}$ data of orifices with various multi-hole geometries. $\mathrm{C}_{\mathrm{v}}$ prime was defined as:

$$
\mathrm{C}_{\mathrm{v}}{ }^{\text {prime }}=\mathrm{C}_{\mathrm{v}} /[(\text { total perimeter of holes/perimeter of pipe })]
$$

\subsection{Flow Head Loss Coefficients and Reynolds Numbers}

Two dimensionless flow head loss coefficients were used in this work. Their definitions are:

$$
\mathrm{K}_{\mathrm{Lh}}=\left(\mathrm{P}_{1}-\mathrm{P}_{2}\right) /\left(0.5 \rho_{\mathrm{L}} \mathrm{u}_{0}^{2}\right) \quad \text { and } \quad \mathrm{K}_{\mathrm{LP}}=\left(\mathrm{P}_{1}-\mathrm{P}_{2}\right) /\left(0.5 \rho_{\mathrm{L}} \mathrm{u}_{\mathrm{p}}^{2}\right)
$$

$\mathrm{K}_{\mathrm{Lh}}$ is based on the hole's dynamic pressure, whereas $\mathrm{K}_{\mathrm{LP}}$ is based on the pipe's dynamic pressure with $u_{p}$ being the average flow velocity in the pipe. Additionally, two Reynolds numbers were used, one based on the hole average velocity and the other one on the pipe average velocity:

$$
\mathrm{Re}_{\mathrm{o}}=\rho_{\mathrm{L}} \mathrm{u}_{\mathrm{o}} \mathrm{d}_{\mathrm{o}} / \mu_{\mathrm{L}} \quad \text { and } \quad \mathrm{Re}_{\mathrm{p}}=\rho_{\mathrm{L}} \mathrm{u}_{\mathrm{p}} \mathrm{D} / \mu_{\mathrm{L}}
$$

where $d_{o}$ and $D$ are the hole diameter and the pipe inside diameter, respectively. $\mu_{L}$ is the liquid dynamic viscosity at the operating temperature.

\subsection{Inter-relationships Among the Aforementioned Dimensionless Numbers}

$\mathrm{K}_{\mathrm{Lh}}$ is related to $\mathrm{K}_{\mathrm{LP}}$ by (Maynes et al. [12]) Eq. (1):

$$
\mathrm{K}_{\mathrm{Lh}}=\left(\mathrm{A}_{\mathrm{h}} / \mathrm{A}_{\mathrm{p}}\right)^{2} \mathrm{~K}_{\mathrm{LP}}
$$

and $\mathrm{Re}_{\mathrm{p}}$ is related to $\mathrm{Re}_{\mathrm{o}}$ by Eq. (2):

$$
\operatorname{Rep}_{\mathrm{P}}=\operatorname{Re}_{\mathrm{o}}\left[\mathrm{n}\left(\mathrm{A}_{\mathrm{h}} / \mathrm{A}_{\mathrm{p}}\right)\right]^{0.5}
$$

where $\mathrm{n}$ is the number of holes in the orifice (hole count) and $\mathrm{A}_{h} / \mathrm{A}_{\mathrm{p}}$ is the ratio of the total area of holes to the pipe cross-sectional area as pointed out earlier. Additionally, $\sigma$ is related to $\mathrm{C}_{\mathrm{v}}$ by Eq. (3):

$$
\sigma=\mathrm{C}_{\mathrm{v}} / \mathrm{K}_{\mathrm{Lh}}
$$

The relationships represented by Eqs. (1) to (3) can be easily obtained by considering the given definitions of the dimensionless numbers involved.

The orifices' $\mathrm{HC}$ tabulated data of Table 1 references constituted experimental values of $\mathrm{P}_{1}, \mathrm{C}_{\mathrm{v}}$, $\mathrm{u}_{\mathrm{o}}, \mathrm{A}_{\mathrm{h}} / \mathrm{A}_{\mathrm{p}}$, flow rate, and temperature. $\mathrm{P}_{2}$ values were either given or calculated using the above relationships, where it was confirmed that its value was virtually one atm. abs. in all cases. Eq. (3) was used to calculate the corresponding $\sigma$ values.

\section{SPECIFIC CORRELATIONS OF ORIFICES' CAVITATING FLOW DIMENSIONLESS NUMBERS AND THEIR UTILITY IN DESIGN}

Cavitating flow is a complex phenomenon that is still not-well understood and whose theoretical basis has not been fully established. Consequently, an empirical approach is usually adopted (Burzio et al. [18]). Accordingly, Eqs. (4) to (18) are empirical; only 
characterized by values of the determination coefficient $\mathrm{R}^{2}>0.9$. Furthermore, the data upon which they are based (Table 1) lacked standard deviation bounds which compromise their accuracy. Notwithstanding these limitations, the equations are of use in a priori design of HC pilot-scale units (as elucidated in section 4.5) where plus or minus 5\% off specification is usually acceptable.

Table 2 expounds the types of correlations employed and equations designation as related to five orifice geometries. Two other geometries pertaining to the $2 \mathrm{~mm}$ and $3 \mathrm{~mm}$ single hole orifices were excluded from the said correlations due to their trend-lacking scattered data. Additionally, Eqs. 13 to 15 were also excluded from Table 2 because they represent a test for $\mathrm{C}_{\mathrm{v}}{ }^{\text {prime }}$ as a unifying parameter.

Table 2: Types of correlation, equations designation and corresponding orifice geometries

\begin{tabular}{cccccc}
\hline Correlation type & $\mathbf{2 m m - 8 h}$ & $\mathbf{2 m m - 3 3 h}$ & $\mathbf{3 m m - 1 6 h}$ & $\mathbf{3 m m - 2 0 h}$ & $\mathbf{5 m m - 8 h}$ \\
\hline $\mathrm{K}_{\text {Lh vs. } \mathrm{Re}_{\mathrm{o}}}$ & Eq. (4) & ------- & ------- & Eq. (5) & ------- \\
$\mathrm{K}_{\text {Lh vs. } \mathrm{C}_{\mathrm{v}}}$ & Eq. (6) & ------- & ------- & Eq. (7) & -------- \\
$\sigma$ vs. $\mathrm{Re}_{\mathrm{o}}$ & Eq. (8) & Eq. (9) & ------- & -------- & Eq. (10) \\
$\sigma$ vs. $\mathrm{C}_{\mathrm{v}}$ & Eq. (11) & Eq. (12) & Eq. (16) & Eq. (17) & Eq. (18) \\
\hline
\end{tabular}

Notes: (i) In the design procedure, the value of $\mathrm{C}_{\mathrm{v}}$ is initially assumed depending on the application (see sec. 4.5) which leads to the calculation of $\mathrm{Re}_{0}$. (ii) For a selected geometry, $\mathrm{K}_{\mathrm{Lh}}$ or $\sigma$ is then determined from an appropriate equation(s) leading to the value of $\mathrm{P}_{1}$ (a prime design parameter). (iii) There are 4 choices to accomplish note (ii) for $2 \mathrm{~mm}-8 \mathrm{holes}, 3$ choices for $3 \mathrm{~mm}-20$ holes, 2 choices for either $2 \mathrm{~mm}$-33holes or $5 \mathrm{~mm}$-8holes, but only one choice for the $3 \mathrm{~mm}$ - 16 holes geometry.

\section{1 $K_{L h} v_{s} \operatorname{Re}_{0}$ Correlations}

For this category, only two specific correlations were obtained as shown in Fig. 1.

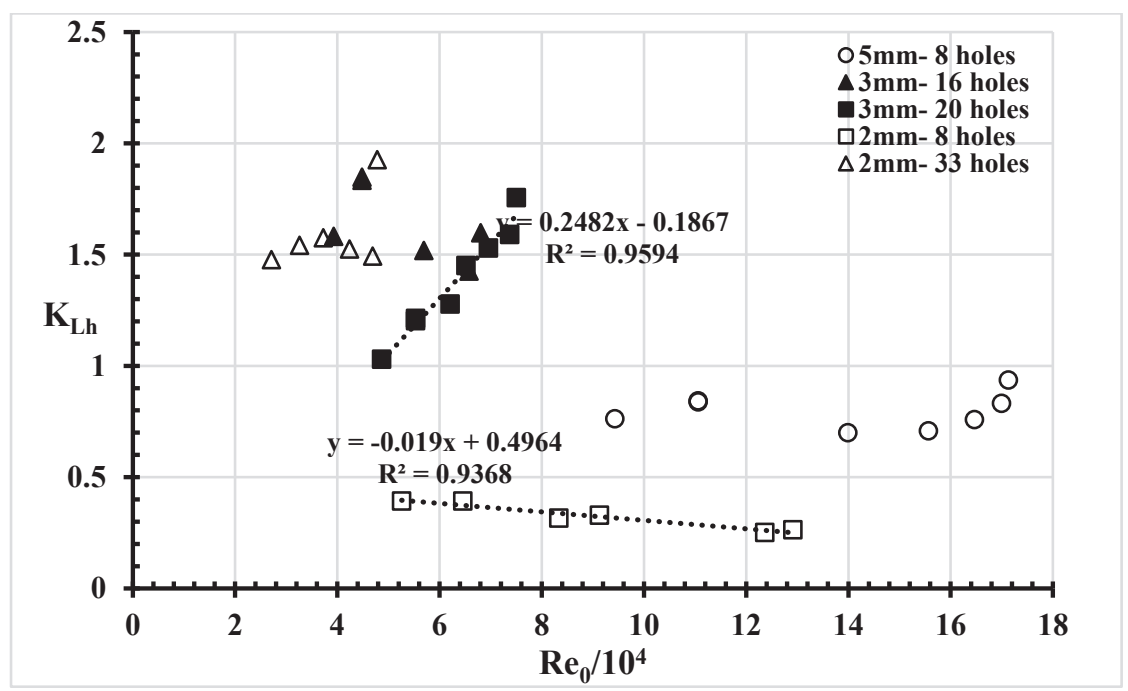

Fig. 1: KLh Vs $\operatorname{Re}_{\mathrm{o}} / 10^{4}$.

$\mathrm{K}_{\mathrm{Lh}}=0.4964-0.019\left(\mathrm{Re}_{\mathrm{o}} / 10^{4}\right)$

(2mm-8holes, $5 \leq \mathrm{Re}_{\mathrm{o}} / 10^{4} \leq 13, \mathrm{R}^{2}=0.9368$ )

$\mathrm{K}_{\mathrm{Lh}}=0.2482\left(\mathrm{Re}_{\mathrm{o}} / 10^{4}\right)-0.1876$

(3mm-20holes, $\left.4.5 \leq \mathrm{Re}_{\mathrm{o}} / 10^{4} \leq 8, \mathrm{R}^{2}=0.9594\right)$ 
The trends of Eqs. (4) and (5) are opposite to one another. The $2 \mathrm{~mm}$-8holes $\mathrm{K}_{\mathrm{Lh}}$ decreases with increasing $\operatorname{Re}_{o}\left(\mathrm{~A}_{\mathrm{h}} / \mathrm{A}_{\mathrm{p}}=2.2 \%\right)$ whereas the $3 \mathrm{~mm}$-20holes $\mathrm{K}_{\mathrm{Lh}}$ increases $\left(A_{h} / A_{p}=12 \%\right)$. Also shown in Fig. 1 are the data of the $2 m m-33$ holes $\left(A_{h} / A_{p}=9.1 \%\right)$ and the $5 \mathrm{~mm}$-8holes $\left(\mathrm{Ah} / \mathrm{A}_{\mathrm{p}}=13.85 \%\right)$. The former reflects an increasing-decreasing trend, whilst the latter depicts a clearly non-linear increasing trend for $\mathrm{Re}_{\mathrm{o}}>16 \times 10^{4}$. Maynes et al. [12] had shown an increasing $K_{L h}$ trend with increasing $u_{o}$ for two multi-hole orifices with $A_{h} / A_{p}$ values of $22 \%$ and $44 \%$ which they attributed to cavitating flow, since according to their results for non-cavitating flow $K_{L h}$ was constant and independent of $u_{o}$. Any explanation for the above observations would be premature at this stage.

\section{2 $\mathrm{K}_{\mathrm{Lh}}$ vs $\mathrm{C}_{\mathrm{v}}$ Correlations}

The following specific correlations were obtained for this category.

$\mathrm{K}_{\mathrm{Lh}}=1.0192 \mathrm{C}_{\mathrm{V}}+0.2095$

(2mm-8holes, $0.045 \leq \mathrm{C}_{\mathrm{v}} \leq 0.56, \mathrm{R}^{2}=0.9956$, Fig. 2)

$\mathrm{K}_{\mathrm{Lh}}=0.862 \mathrm{C}_{\mathrm{V}}{ }^{-0.567}$

(3mm-20holes, $0.3 \leq \mathrm{C}_{\mathrm{v}} \leq 0.75, \mathrm{R}^{2}=0.9681$, Fig. 3)

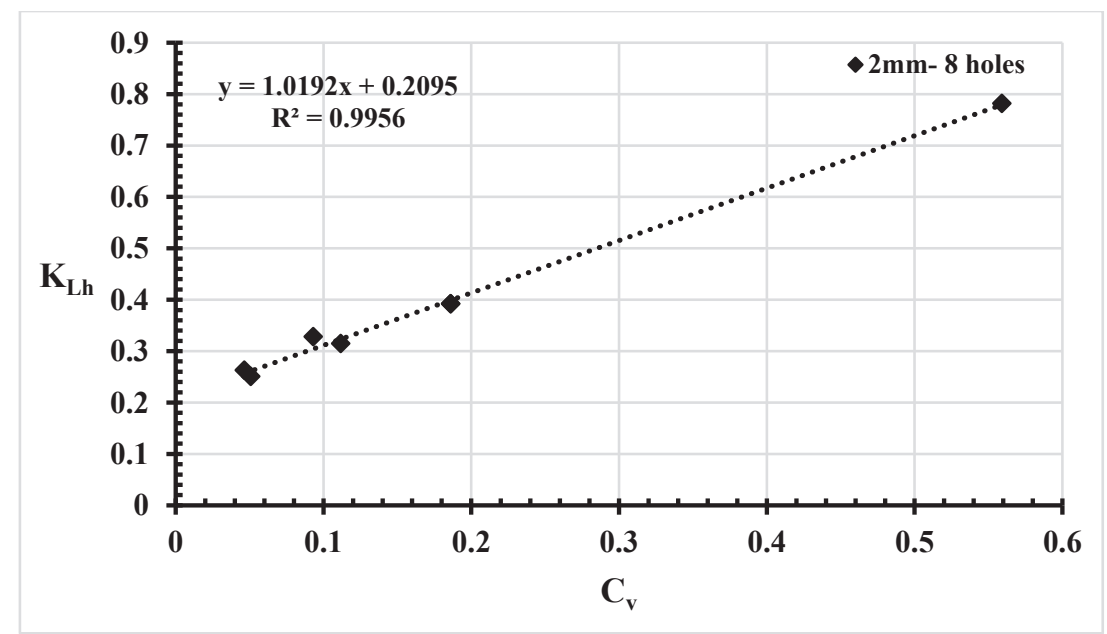

Fig. 2: $\mathrm{K}_{\mathrm{Lh}}$ vs $_{\mathrm{V}}$ 2mm-8holes.

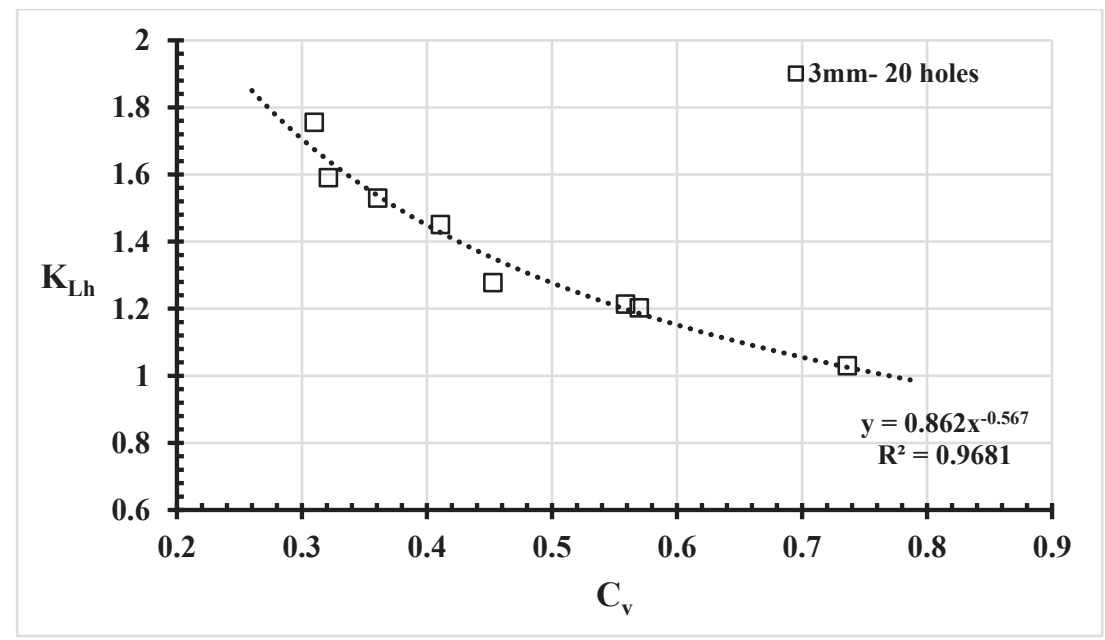

Fig. 3: $\mathrm{K}_{\mathrm{Lh}}$ vs $\mathrm{C}_{\mathrm{v}} 3 \mathrm{~mm}-20$ holes. 
The trends represented by Eqs. (6) and (7) are opposite to one another. For each geometry, the above trend is the reverse of its $\mathrm{K}_{\mathrm{Lh}}$ vs $\mathrm{Re}_{o}$ trend [Eqs. (4) and (5)]. Hence, $\mathrm{K}_{\mathrm{Lh}}$ increases with increasing $C_{v}$ for the geometry of the $2 \mathrm{~mm}-8$ holes [Eq. (6)] whereas it decreases for the $3 \mathrm{~mm}-20$ holes one [Eq. (7)].

\section{$4.3 \sigma$ vs $\operatorname{Re}_{0}$ Correlations}

For this category, the following specific relationships were obtained:

$$
\sigma=0.8139-0.0159\left(\operatorname{Re}_{\mathrm{o}} / 10^{4}\right)
$$

(2mm-8holes, $3.7 \leq \mathrm{Re}_{\mathrm{o}} / 10^{4} \leq 13, \mathrm{R}^{2}=0.9095$, Fig. 4)

$$
\sigma=1.0317-0.1757\left(\operatorname{Re}_{\mathrm{o}} / 10^{4}\right)
$$

(2mm-33holes, $3 \leq \mathrm{Re}_{\mathrm{o}} / 10^{4} \leq 5, \mathrm{R}^{2}=0.9644$, Fig. 4)

$$
\sigma=65.504\left(\operatorname{Re}_{\mathrm{o}} / 10^{4}\right)^{-2.027}
$$

(5mm-8holes, $9 \leq \mathrm{Re}_{\mathrm{o}} / 10^{4} \leq 17.5, \mathrm{R}^{2}=0.9559$, Fig. 5)

Equations (8) to (10) indicate a decreasing trend of $\sigma$ with increasing $\mathrm{Re}_{\mathrm{o}}$ for different geometries. This was expected since higher $\mathrm{Re}_{o}$ values imply higher $\mathrm{P}_{1}$ values making $\sigma$ smaller since $\mathrm{P}_{2}$ and $\mathrm{P}_{\mathrm{v}}$ are fixed, $\left[\sigma=\left(\mathrm{P}_{2}-\mathrm{P}_{\mathrm{v}}\right) /\left(\mathrm{P}_{1}-\mathrm{P}_{2}\right)\right]$.

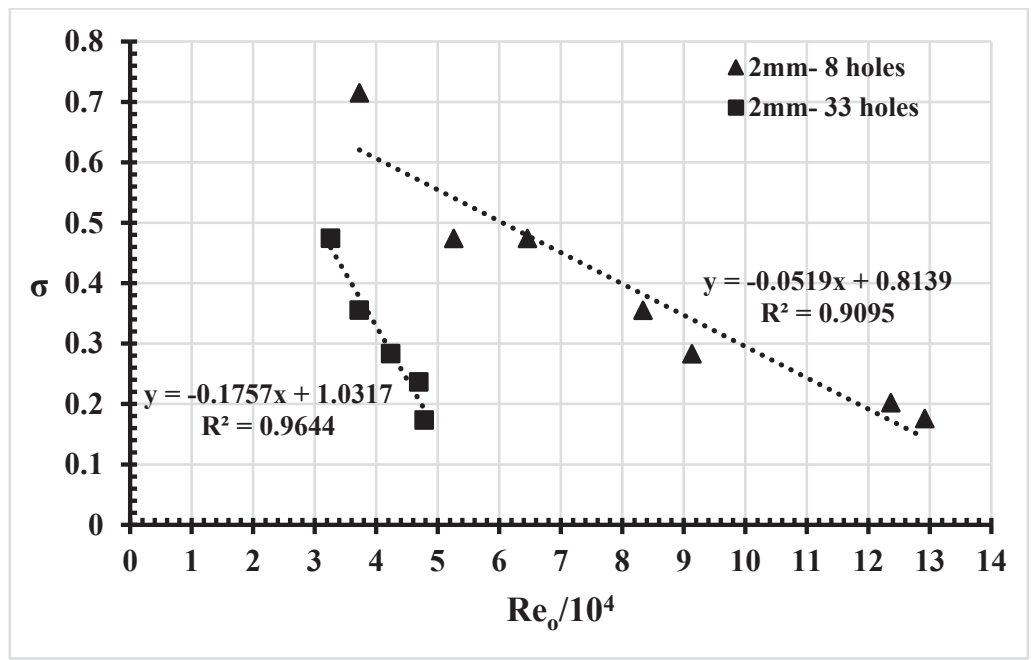

Fig. 4: $\sigma$ vs $\operatorname{Re}_{\mathrm{o}} / 10^{4}$ for $2 \mathrm{~mm}-8$, 33holes.

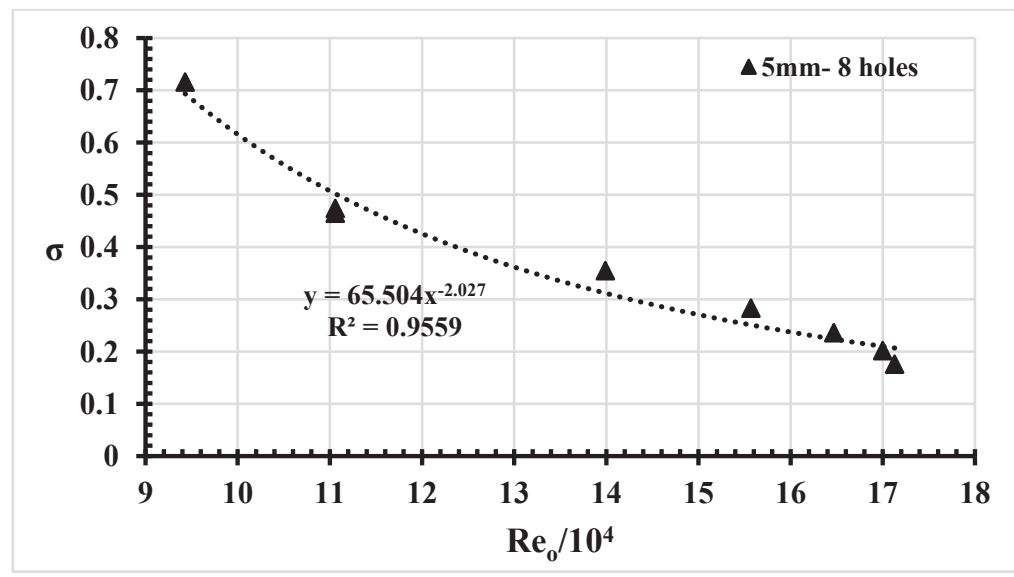

Fig. 5: $\sigma$ vs $\mathrm{Re}_{\mathrm{o}} / 10^{4}$ for $5 \mathrm{~mm}-8$ holes. 


\section{$4.4 \sigma$ vs $C_{v}$ or $C_{v}{ }^{\text {prime }}$ Correlations}

Specific correlations linking the two most widely-used definitions of cavitation number were as follows:

$$
\sigma=1.016 \mathrm{C}_{\mathrm{v}}^{0.5509}
$$

(2mm-8 oles, $0.045 \leq \mathrm{C}_{\mathrm{v}} \leq 0.56, \mathrm{R}^{2}=0.9647$, Fig. 6$)$

$$
\sigma=0.6848 \mathrm{C}_{\mathrm{v}}-0.0262
$$

(2mm-33 holes, $0.35 \leq \mathrm{C}_{\mathrm{v}} \leq 0.75, \mathrm{R}^{2}=0.9799$, Fig. 6)

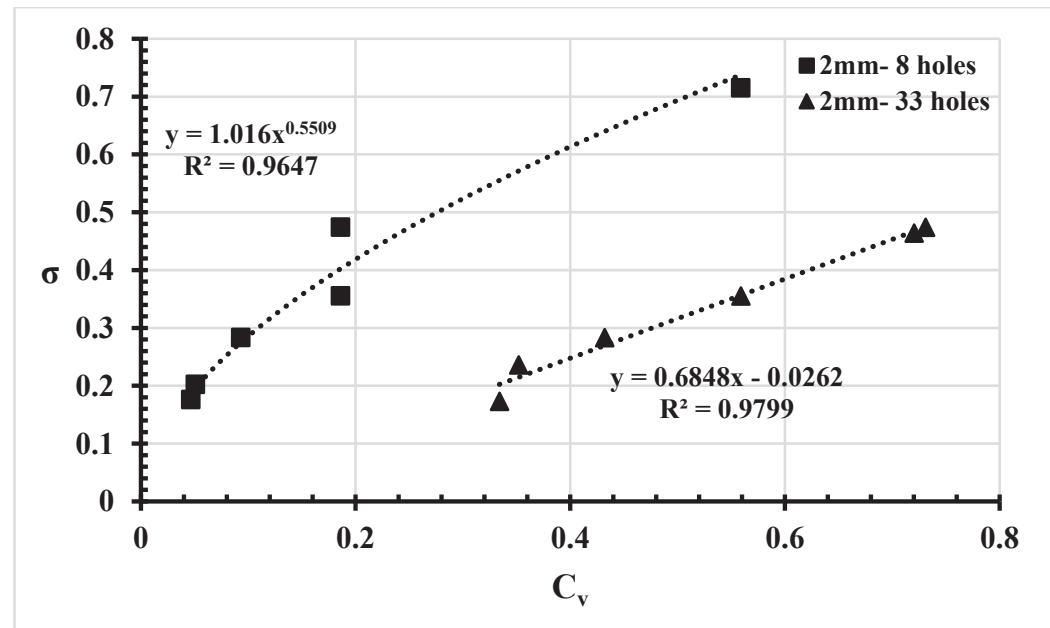

Fig. 6: $\sigma$ vs $\mathrm{Cv}$ for $2 \mathrm{~mm}-8$, 33holes.

The two geometries of Eqs. (11) and (12) were combined by a single $\sigma$ vs $\mathrm{C}_{\mathrm{v}}$ prime correlation:

$$
\sigma=0.9478 \mathrm{C}_{\mathrm{v}}^{\text {prime }}+0.0593
$$

(2mm-8, 33 holes, $0.1 \leq \mathrm{C}_{\mathrm{v}}{ }^{\text {prime }} \leq 0.45, \mathrm{R}^{2}=0.9388$, Fig. 7)

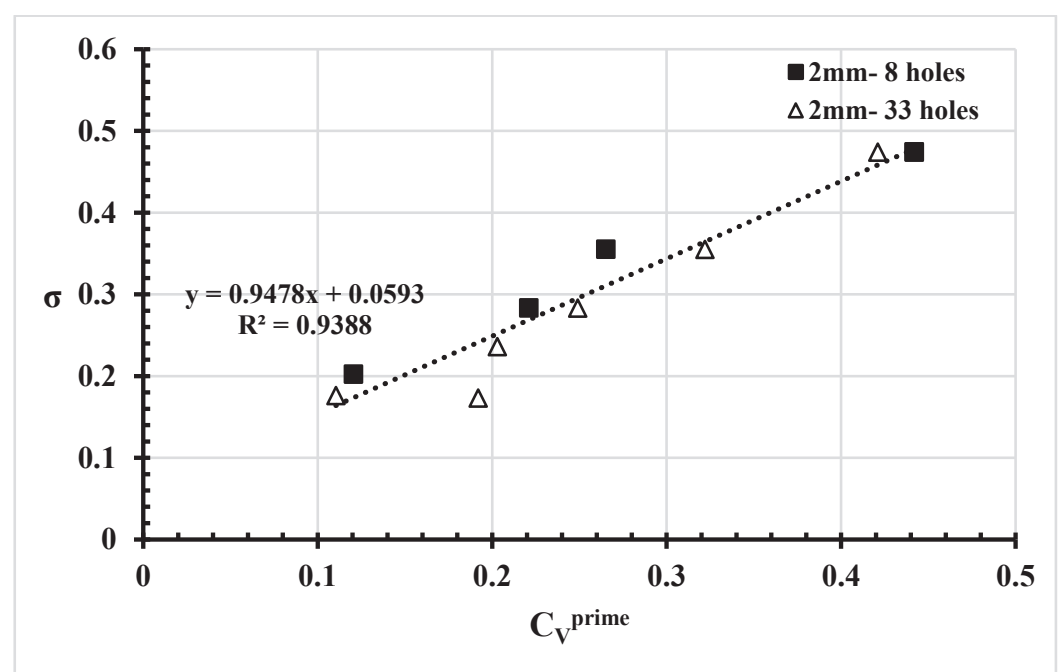

Fig. 7: $\sigma \mathrm{vs} \mathrm{C}_{\mathrm{v}}{ }^{\text {prime }}$ for combined $2 \mathrm{~mm}-8$, 33 holes. 
Equation (13) is the only case where $\mathrm{C}_{\mathrm{v}}$ prime acted as a unifying parameter. Consequently, two additional $\sigma$ vs $C_{\mathrm{v}}$ specific relationships were deduced for imaginary geometries of 2mm-16holes and 2mm-20holes:

$$
\begin{aligned}
& \sigma=1.1255 \mathrm{C}_{\mathrm{v}}+0.0593 \\
& \left(2 \mathrm{~mm}-16 \text { holes, } 0.0842 \leq \mathrm{C}_{\mathrm{v}} \leq 0.379\right) \\
& \sigma=0.9004 \mathrm{C}_{\mathrm{v}}+0.0593 \\
& \left(2 \mathrm{~mm}-20 \text { holes, } 0.1053 \leq \mathrm{C}_{\mathrm{v}} \leq 0.477\right)
\end{aligned}
$$

Additionally, the following specific $\sigma$ vs $\mathrm{C}_{\mathrm{v}}$ correlations were obtained:

$$
\sigma=0.5995 \mathrm{C}_{\mathrm{v}}-0.0081
$$

(3mm-16holes, $0.37 \leq \mathrm{C}_{\mathrm{v}} \leq 1.15, \mathrm{R}^{2}=0.9602$, Fig. 8)

$\sigma=1.2227 \mathrm{C}_{\mathrm{V}}-0.206$

(3mm-20holes, $0.3 \leq \mathrm{C}_{\mathrm{v}} \leq 0.75, \mathrm{R}^{2}=0.9936$, Fig. 8)

$\sigma=1.2676 \mathrm{C}_{\mathrm{v}}$

(5mm-8holes, $0.15 \leq \mathrm{C}_{\mathrm{v}} \leq 0.55, \mathrm{R}^{2}=0.9732$, Fig. 9)

Equations (11) to (18) reflect a trend of increasing $\sigma$ with increasing $\mathrm{C}_{\mathrm{v}}$ for the various orifice geometries. This trend was also expected since an increase in $\mathrm{C}_{\mathrm{v}}$ value means a lower $\mathrm{u}_{0}$ value which entails a lower $\mathrm{P}_{1}$ value leading to an increase in the value of $\sigma$.

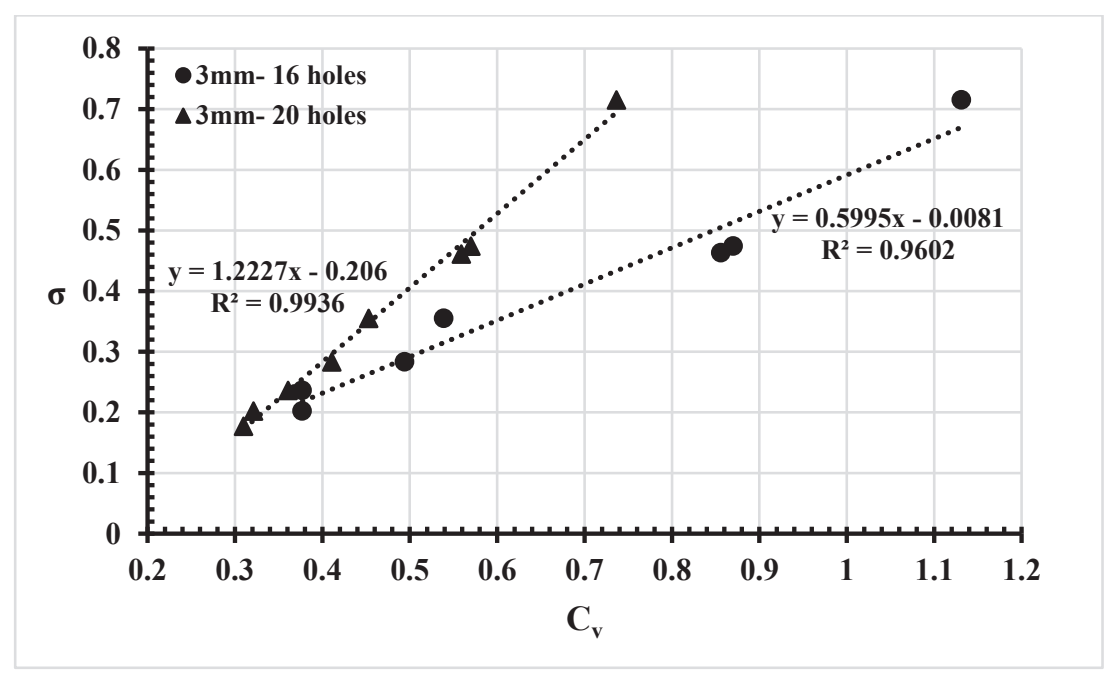

Fig. 8: $\sigma$ vs Cv for 3mm-16, 20holes.

Yan and Thorpe [13] derived a theoretical equation linking $\sigma$ to $\mathrm{C}_{\mathrm{v}}$ for a single hole orifice. Their relationship included the orifice's discharge coefficient $\mathrm{C}_{\mathrm{d}}$, its contraction coefficient $C_{c}$, and $A_{h} / A_{p}$. It was not possible to compare Eqs. (11) to (18) with their equation because $C_{d}$ and $C_{c}$ were not given for the orifices under consideration in this work. Estimating the values of $C_{d}$ and $C_{c}$ from correlations available in the literature would be uncertain since they are related to the aspect ratio, which is also missing for all the multi-hole orifices of Table 1. 


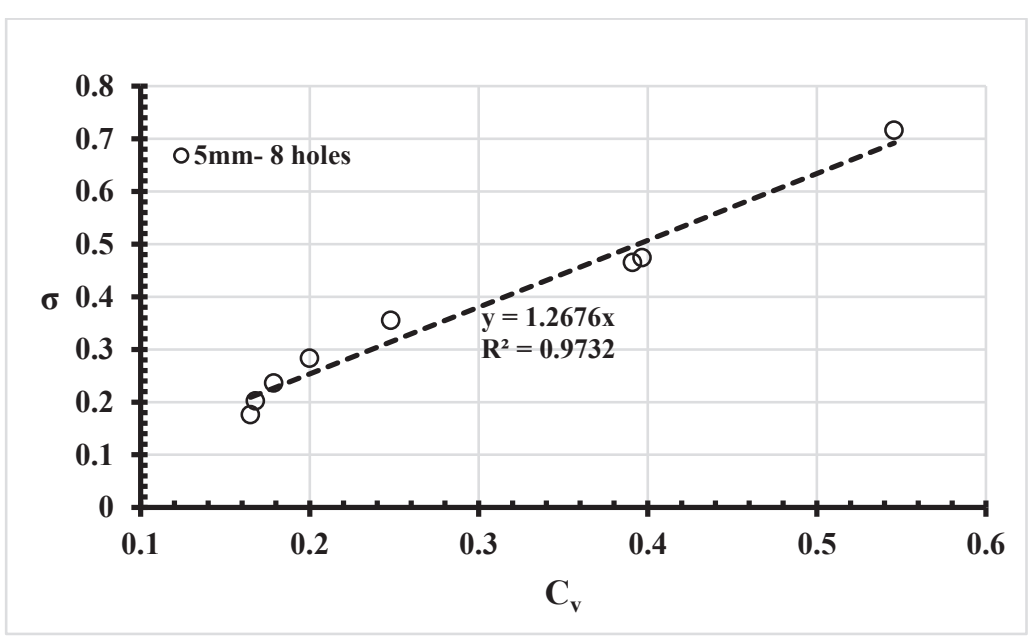

Fig. 9: $\sigma$ vs Cv for $5 \mathrm{~mm}-8$ holes.

\subsection{Outline of a Priori Design Procedure Utilising the Specific Correlations}

(a) Initially an appropriate $\mathrm{C}_{\mathrm{v}}$ value for the intended application is chosen, e.g. for wastewater containing bio-refractory organic dyes, a suitable range is $0.2 \leq \mathrm{C}_{\mathrm{v}} \leq 0.4$ (Rajoriya et al. [19])

(b) Since $\mathrm{C}_{\mathrm{v}}=\left(\mathrm{P}_{2}-\mathrm{P}_{\mathrm{v}}\right) /\left(0.5 \rho \mathrm{L} \mathrm{u}_{\mathrm{o}}^{2}\right)$, $\mathrm{u}_{\mathrm{o}}$ can be determined after an operating temperature is set, fixing the values of $\mathrm{P}_{\mathrm{v}}, \rho \mathrm{L}$, and $\mu_{\mathrm{L}}$. Hence the value of $\mathrm{Re}_{\mathrm{o}}$ can be established.

(c) After selecting an orifice geometry, one or more correlation may be used to calculate either $\mathrm{K}_{\mathrm{Lh}}$ or $\sigma$ from which the value of $\mathrm{P}_{1}$ can be determined. This $\mathrm{P}_{1}$ value is based on $38 \mathrm{~mm}$ (1.5 inch) pipe diameter (see Table 1).

(d) The $38 \mathrm{~mm}$-based $\mathrm{P}_{1}$ value can be lowered by specifying a larger pipe diameter, e.g. $53 \mathrm{~mm}$ ( 2 inch) according to the findings of sec. 5 below. $\left(\mathrm{P}_{1}-\mathrm{P}_{2}\right)$ represents the main pressure drop of the system whose volumetric flow rate $(\mathrm{Q})$ can be calculated from the value of $u_{o}$ and the selected geometry leading to the estimation of the system's total pressure drop $(\Delta \mathrm{P})$.

(e) A centrifugal pump whose best efficieny point (BEP) matches the system's Q- $\Delta \mathrm{P}$ point should be employed. Conversely, if a pump is already available, an appropriate $\mathrm{C}_{\mathrm{v}}$ value, the ensuing $\mathrm{P}_{1}$ and reduced $\mathrm{P}_{1}$ values, and selected geometry should be manipulated to achieve the pump's BEP-system's Q- $\Delta \mathrm{P}$ match.

\section{GENERAL KLP VS ReP CORRELATION AND ITS IMPLICATIONS}

Figure 10 shows a plot of $\mathrm{K}_{\mathrm{LP}}$ vs. $\mathrm{Re}_{\mathrm{p}}$ for all the HC data of the orifices listed in Table 1, including the single hole data which were excluded from the specific correlations of sec. 4 due to their trend-lacking scatter. It is noteworthy that four pipe sizes are included in Fig. 10 with a range of $19 \leq$ I.D. $\leq 38 \mathrm{~mm}$, which is in contrast with the specific correlations where only a single pipe size of I.D $=38 \mathrm{~mm}$ was involved. The unifying characteristic of $K_{L P} v s R_{p}$ is clear, resulting in the following general correlation Eq. (19):

$$
\begin{aligned}
& K_{L P}=4228.5\left(\operatorname{Re}_{p} / 10^{4}\right)^{-1.6707} \\
& \left\{\left(\operatorname{Re}_{p} / 10^{4}\right) \leq 18, R^{2}=0.9353\right\}
\end{aligned}
$$


Retrieving the definitions of $K_{L P}=\left(P_{1}-P_{2}\right) /\left(0.5 \rho_{L} u_{p}^{2}\right)$ and $R_{p}=\left(\rho_{L} u_{p} D\right) / \mu_{L}$, Fig. 10 indicates that increasing $\mathrm{Re}_{\mathrm{p}}$ by increasing $\mathrm{u}_{\mathrm{p}}$, which can only come about by increasing $\mathrm{P}_{1}$ reduces $K_{L P}$ in a nearly exponential decay manner. If the definitions of $K_{L P}$ and $R_{p}$ are substituted into Eq. (19) and noting that $\left(\mathrm{P}_{1}-\mathrm{P}_{2}\right)$ may be replaced by $\mathrm{P}_{1}$ as gage pressure, then Eq. (19) can take the following form:

$$
\mathrm{P}_{1}=1.0185 \times 10^{5} \rho \mathrm{L}^{-0.6707} \mu_{\mathrm{L}}^{1.6707} \mathrm{up}_{\mathrm{p}}^{0.3293} \mathrm{D}^{-1.6707}
$$

where $\mathrm{P}_{1}$ has units of bar gage.

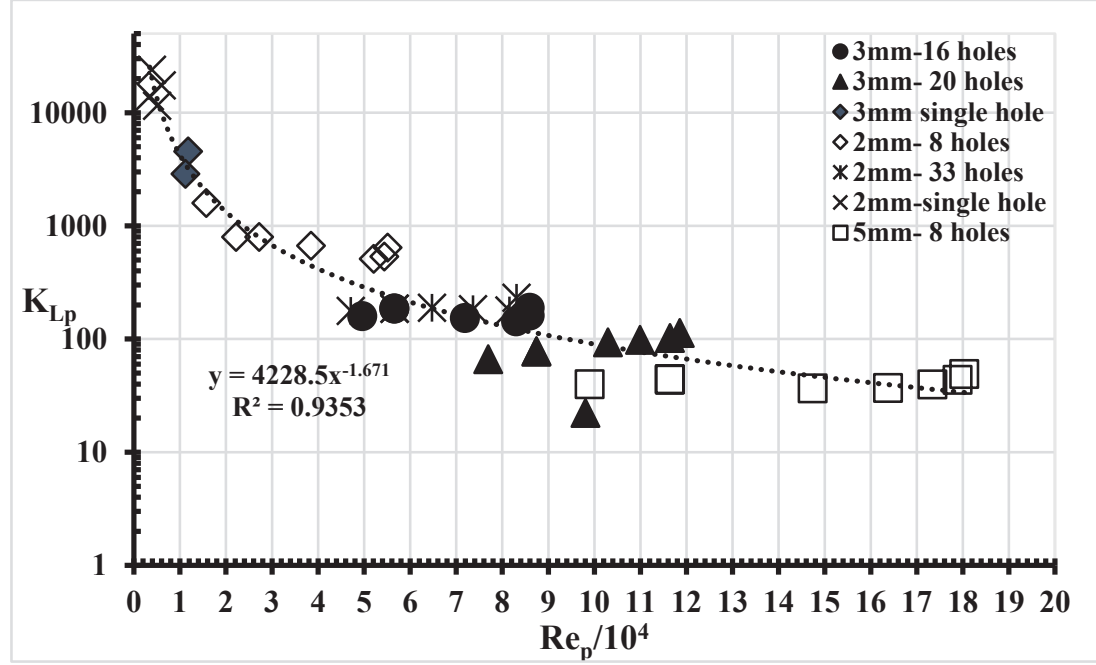

Fig. 10: $\mathrm{K}_{\mathrm{LpVs}} \mathrm{R}_{\mathrm{ep}} / 10^{4}$ for all single and multi-hole orifices.

If for a specific orifice geometry and a desired $\mathrm{C}_{\mathrm{v}}$ value, two pipes are considered (in which the specified orifice is to be installed in one of them) one pipe with a smaller inside diameter Ds and the other with a larger inside diameter $D_{L}$, then the application of Eq. (20) and the equation of continuity (conservation of mass flow rate) for the two pipes will result in the following ratio Eq. (21): (see Appendix A),

$$
\left(\mathrm{P}_{1} \text { in } \mathrm{D}_{\mathrm{L}} \text { pipe } / \mathrm{P}_{1} \text { in } \mathrm{D}_{\mathrm{S}} \text { pipe }\right)=\left(\mathrm{D}_{\mathrm{S}} / \mathrm{D}_{\mathrm{L}}\right)^{\mathbf{2 . 3 3}}
$$

Hence, a lower value of $\mathrm{P}_{1}$ is required to obtain the desired $\mathrm{C}_{\mathrm{v}}$ value by installing the specified orifice in a larger I.D pipe compared to a smaller I.D. pipe. It is emphasized that this result is limited to the applicability range of Eq. (19) and the data upon which it is based.

An additional advantage of using a relatively larger inside diameter pipe is the lower pressure drop in the system, apart from the orifice's pressure drop $\left(\mathrm{P}_{1}-\mathrm{P}_{2}\right)$, especially when the required number of passes is large. This will have a positive effect on the expended energy and consequently on the cavitation yield.

A possible drawback of lowering $\mathrm{P}_{1}$ value by using a larger inside diameter pipe is the ensuing decrease in the value of the cavity collapse pressure given by the following empirical correlation [14-16] Eq. (22).

$$
\mathrm{P}_{\text {collapse }}=7527\left[100\left(\mathrm{Ah}_{\mathrm{h}} / \mathrm{A}_{\mathrm{p}}\right)\right]^{-2.55} \mathrm{P}_{1}^{2.46} \mathrm{Ro}_{\mathrm{o}}^{-0.8} \mathrm{do}^{2.37}
$$

which is related to the cavitation yield by Eq. (23): 


$$
\mathrm{CY}=\mathrm{K}\left(\mathrm{P}_{\text {collapse }}\right)^{\mathbf{W}}
$$

where $R_{o}$ is the initial cavity size, $\mathrm{K}$ and $\mathrm{w}$ are constants whose values depend on the system's particulars (device geometry, operating parameters, type of reaction). However, the possible negative effect of lower $\mathrm{P}_{1}$ value may be partially or totally offset by the decrease in the value of $A_{h} / A_{p}$ with a larger inside diameter pipe and/or the value of $w$ being positive or negative.

Applying Eq. (22) with Ds or DL leads to:

$$
\left(\mathrm{P}_{\text {collapse in }} \mathrm{D}_{\mathrm{L}} \text { pipe }\right) /\left(\mathrm{P}_{\text {collapse }} \text { in } \mathrm{D}_{\mathrm{S}} \text { pipe }\right)=\left(\mathrm{D}_{\mathrm{S}} / \mathrm{D}_{\mathrm{L}}\right)^{\mathbf{0 . 6 3 2}}
$$

\section{COMPARISON WITH FINDINGS OF MAYNES et al. [12]}

Maynes et al. [12] showed a graphical representation of $K_{L h}$ vs $A_{h} / A_{p}$ in which data points pertaining to 16 multi-hole orifices of their work plus data points from three references were all bounded by two theoretical models, namely Eqs. (25) and (26):

$$
\begin{aligned}
& \left(\mathrm{K}_{\text {Lh }}\right)_{\text {Detached }}=\left[\mathrm{C}^{-1}-\left(\mathrm{A}_{\mathrm{h}} / \mathrm{A}_{\mathrm{p}}\right)\right]^{2} \\
& \left(\mathrm{~K}_{\text {Lh }}\right)_{\text {Attached }}=2\left[1-\left(\mathrm{A}_{\mathrm{h}} / \mathrm{A}_{\mathrm{p}}\right)-\mathrm{C}^{-1}\right]+\mathrm{C}^{-2}+\left(\mathrm{A}_{\mathrm{h}} / \mathrm{A}_{\mathrm{p}}\right)^{2}
\end{aligned}
$$

These models were derived by Testud et al. [10] for single hole orifice using Bernoulli's principle and conservation of momentum for non-cavitating flow. Eq. (25) is relevant to a thin orifice where the flow does not reattach within the hole, whereas Eq. (26) is for a thick orifice where the flow is reattached. $\mathrm{C}_{\mathrm{c}}$ value for $\mathrm{Eq}$. (25) was determined from Busemann theoretical relation cited by Maynes et al. [12] (a function of $A_{h} / A_{p}$ ) whilst for Eq. (26) it was given a fixed value of 0.75. Maynes et al. emphasized that all the shown data were non-cavitating/incipient-cavitation points. However, the two included points from Testud et al. are developed cavitation results (one for a single hole and the other for multi-hole orifices with aspect ratios of 0.64 and 4.67 , respectively).

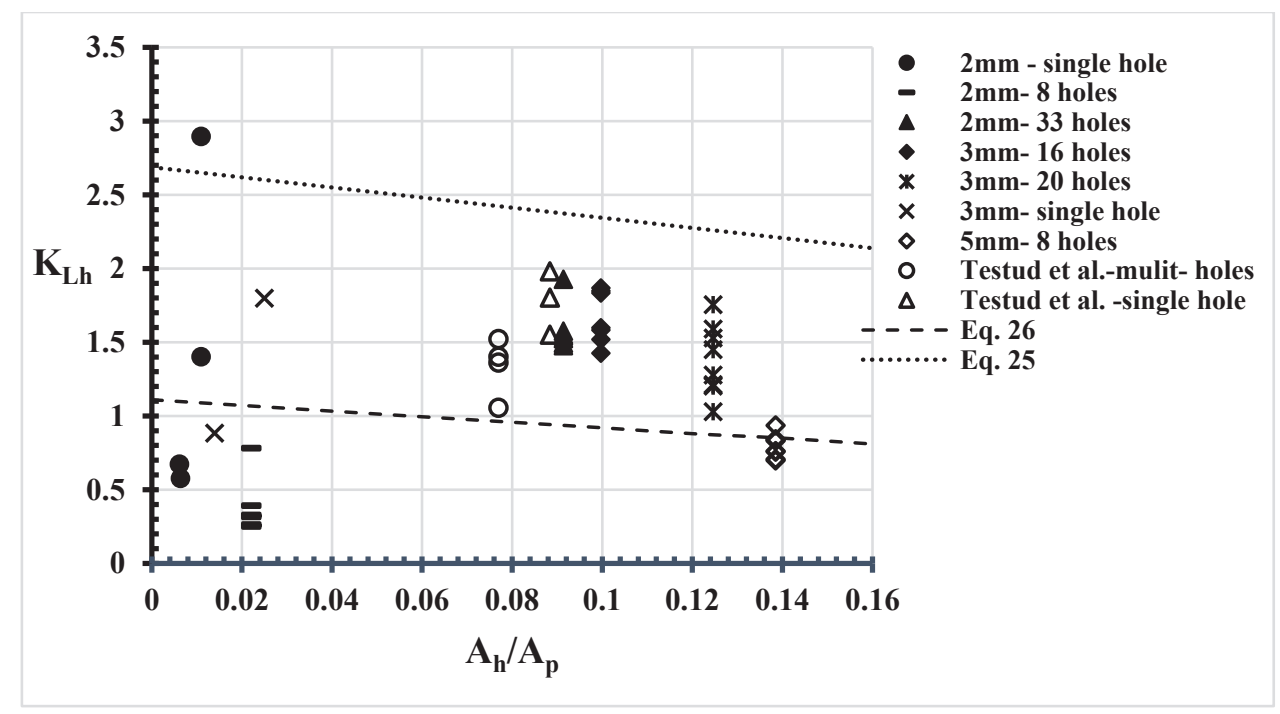

Fig. 11: KLh vs $\mathrm{A}_{h} / \mathrm{A}_{\mathrm{p}}$ for all single and multi-hole orifices.

Figure 11 is a reproduction of Maynes et al. [12] presentation where the upper line represents Eq. (25) and the lower line Eq. (26). The plotted points are all the data of Table 
1 plus all the developed cavitation results of Testud et al. [10]. Hence, all the points in Fig. 11 are cavitating flow results. The $2 \mathrm{~mm}$ and $3 \mathrm{~mm}$ single hole points having very small $\mathrm{A}_{h} / \mathrm{A}_{\mathrm{p}}$ values lie mainly below or in-between the bounds representing Eqs. (25) and (26). As for the multi-hole orifices data and that of Testud et al. [10], there seems to be a trend with increasing value of $\mathrm{Ah}_{\mathrm{h}} / \mathrm{Ap}_{\mathrm{p}}$ starting below the lower bound ( $2 \mathrm{~mm}-8 \mathrm{holes}$ ), then inbetween the two bounds and finally back to the lower bound (5mm-8holes). It is therefore concluded that results falling in-between these two bounds are not necessarily noncavitating/incipient cavitation data and could very well be developed cavitation results.

\section{CONCLUSIONS}

Correlations represented by Eqs. (4) to (12) and Eqs. (16) to (18), although specific to their respective orifice geometries, can be used to design and/or predict the performance of pilot-scale $\mathrm{HC}$ units for wastewater treatment. This includes a priori determination of $\mathrm{P}_{1}$ and $\left(\mathrm{P}_{1}-\mathrm{P}_{2}\right)$ values for the desired $\mathrm{C}_{\mathrm{v}}$ value using a specific orifice geometry. Furthermore, they can be used to design systems to suit available pumps in order to obtain operating points at or very close to the pump's best efficiency points. This will increase the cavitation yield by lowering the value of the expended energy.

The pipe's loss coefficient $K_{L P}$ and the pipe's Reynolds number $\mathrm{Re}_{\mathrm{p}}$ were the only dimensionless parameters that unified all the HC data of orifices of various geometries and pipe sizes in a single general correlation with $\mathrm{R}^{2}=0.9353$. This resultant correlation, Eq. (19), implies that for the same specified orifice geometry and desired $\mathrm{C}_{\mathrm{v}}$ value, using a relatively larger pipe inside diameter entails a reduction in the value of the required upstream pressure $\mathrm{P}_{1}$. The ratio of $\mathrm{P}_{1}$ value in the larger pipe to its value in the smaller pipe is a function of the ratio of the smaller pipe diameter (Ds) to the larger pipe diameter $\left(\mathrm{D}_{\mathrm{L}}\right)$ : $\left(\mathrm{P}_{1}\right.$ in $\left.\mathrm{D}_{\mathrm{L}}\right) /\left(\mathrm{P}_{1}\right.$ in $\left.\mathrm{DS}_{\mathrm{S}}\right)=\left(\mathrm{DS}_{\mathrm{S}} / \mathrm{D}_{\mathrm{L}}\right)^{\mathbf{2 . 3 3}}$. A lower $\mathrm{P}_{1}$ value will increase the cavitation yield by decreasing the expended energy especially if the number of passes is large. However, a lower $\mathrm{P}_{1}$ value will also decrease the value of the cavity collapse pressure which may affect the cavitation yield negatively, positively, or not at all depending on $\mathrm{A}_{\mathrm{h}} / \mathrm{A}_{\mathrm{p}}$ variation and on constants whose values are system-specific.

The findings of Maynes et al. [12] that non-cavitating/incipient cavitation orifices' $\mathrm{K}_{\mathrm{Lh}}$ vs $\mathrm{A}_{\mathrm{h}} / \mathrm{A}_{\mathrm{p}}$ data fall in-between two theoretical models, Eqs. (25) and (26), are not exclusive. Orifices' cavitating flow results may also behave likewise, but with a discernible trend.

\section{REFERENCES}

[1] Braeutigam P, Franke M, Schneider RJ, Lehmann A, Stolle A, Ondruschka B. (2012) Degradation of carbamazepine in environmentally relevant concentrations in water by hydrodynamic-acoustic cavitation (HAC). Water Res., 46:2469-2477.

[2] Patil PN, Bote SD, Gogate PR. (2014) Degradation of imidacloprid using combined advanced oxidation processes based on hydrodynamic cavitation. Ultrason. Sonochem., 21:1770-1777.

[3] Pradham AA, Gogate PR. (2010) Removal of p-nitrophenol using hydrodynamic cavitation and Fenton chemistry at pilot scale operation, Chem. Eng. J., 156:77-82.

[4] Sivakumar M, Pandit AB. (2002) Wastewater treatment: a novel energy efficient hydrodynamic cavitational technique. Ultrason. Sonochem., 9:123-131.

[5] Saharan VK, Pandit AB, Kumar PSS, Anandan S. (2012) Hydrodynamic Cavitation as an Advanced Oxidation Technique for the Degradation of Acid Red 88 Dye. Ind. Eng. Chem. Res., 51:1981-1989. 
[6] Madhu GM, Thomas A, Deepak S, Preetham HS, Rajanandam KS. (2015) Escalation of degradation of malachite green and methyl violet using hydrodynamic cavitation using different orifice geometry. Int. J. Env. Sci., 5(4):880.

[7] Mancuso G, Langone M, Laezza M, Andreottola G. (2016) Decolourization of Rhodamine B: A swirling jet-induced cavitation combined with $\mathrm{NaOCl}$. Ulatrason. Sonochem., 32:1830 .

[8] Rajoriya S, Bargole S, Saharan VK. (2017) Degradation of reactive blue 13 using hydrodynamic cavitation: Effect of geometrical parameters and different oxidizing additives. Ultrason. Sonochem., 37:192-202, DOI:http://doi.org/10.1016/j.ultsonch.2017.01.005

[9] Pawar SK, Mahulkar AV, Pandit AB, Roy K, Moholkar VS. (2017) Sonochemical Effect Induced by Hydrodynamic Cavitation: Comparison of Venturi/Orifice Flow Geometries. AIChE Journal, 63(10):4705-4716.

[10] Testud P, Moussou P, Hirschberg A, Auregan Y. (2007) Noise generated by cavitating single-hole and multi-hole orifices in a water pipe. J. Fluids and Structures, 23:163-189.

[11] Vichare N P, Gogate PR, Pandit AB. (2013) Optimization of hydrodynamic cavitation using a model reaction. Chemical Engineering Technology, 23:683-690.

[12] Maynes D, Holt GJ, Blotter J. (2013) Cavitation Inception and Head loss Due to Liquid Flow Through Perforated Plates of Varying Thickness. J. Fluids Eng., 135: 031302-1— 031302-11.

[13] Yan Y, Thorpe RB. (1990) Flow Regime Transitions Due to Cavitation in the Flow Through an Orifice. Int. J. Multiphase Flow, 16 (6):1023-1045.

[14] Gogate PR, Pandit AB. (2000) Engineering Design Methods for Cavitation Reactors II: Hydrodynamic Cavitation. AIChE J., 46 (8):1641-1649.

[15] Gogate PR, Shirganokar IZ, Sivakumar M, Senthilkumar P, Vichare NP, Pandit AB. (2001) Cavitation Reactors: Efficiency Assessment Using a Model Reaction. AIChE J., 47 (11):2526-2538.

[16] Gogate PR, Pandit AB. (2005) A review and assessment on hydrodynamic cavitation as a technology for the future. Ultrason. Sonochem., 12:21-27.

[17] Carpenter J, Badve M, Rajoriya S, George S, Saharan VK, Pandit AB. (2017) Hydrodynamic cavitation: An emerging technology for the intensification of various chemical and physical processes in a chemical process industry. Reviews in Chemical Engineering, 33(5):433-468. https://doi.org/10.1515/revce-2016-0032.

[18] Burzio E, Bersani F, Caridi GCA, Vesipa R, Ridolfi L, Manes C. (2020) Water disinfection by orifice-induced hydrodynamic cavitation. Ultrasonics-Sonochemistry, 60, 104740: 1-13.

[19] Rajoriya S, Carpenter J, Saharan VK, Pandit AB. (2016) Hydrodynamic cavitation: an advanced oxidation process for the degradation of bio-refractory pollutants. Rev. Chem. Eng., 32: 379-411.

\section{APPENDIX A}

The mass flow rate and volumetric flow rate (Q) will be the same in both $\mathrm{D}_{\mathrm{L}}$ and $\mathrm{D}_{\mathrm{S}}$ pipes, therefore,

$$
\begin{aligned}
& \mathrm{P}_{1} \text { in DL pipe }=1.0185 \times 10^{5} \rho \mathrm{L}^{-0.6707} \mu \mathrm{L}^{1.6707}\left(4 \mathrm{Q} / \pi \mathrm{DL}^{2}\right)^{0.3293} \mathrm{DL}^{-1.6707} \\
& \mathrm{P}_{1} \text { in Ds pipe }=1.0185 \times 10^{5} \rho \mathrm{L}^{-0.6707} \mu \mathrm{L}^{1.6707}\left(4 \mathrm{Q} / \pi \mathrm{Ds}^{2}\right)^{0.3293} \mathrm{Ds}^{-1.6707}
\end{aligned}
$$

Dividing: $\left(\mathrm{P}_{1}\right.$ in $\mathrm{D}_{\mathrm{L}}$ pipe $/ \mathrm{P}_{1}$ in $\mathrm{Ds}_{\mathrm{S}}$ pipe $)=\left(\mathrm{D}_{\mathrm{L}}^{-0.6586} \mathrm{D}_{\mathrm{L}}^{-1.6707}\right) /\left(\mathrm{Ds}^{-0.6586} \mathrm{DS}^{-1.6707}\right)$

$$
=\mathrm{DL}_{\mathrm{L}}^{-2.33} / \mathrm{Ds}^{-2.33}=\left(\mathrm{DS}_{\mathrm{S}} / \mathrm{D}_{\mathrm{L}}\right)^{2.33}
$$

